\title{
STABILITY INDICATING ULTRA PERFORMANCE LIQUID CHROMATOGRAPHIC METHOD FOR SIMULTANEOUS DETERMINATION OF PHENYLEPHRINE HYDROCHLORIDE, CHLORPHENIRAMINE MALEATE, PARACETAMOL, GUAIPHENESIN AND BROMHEXINE HYDROCHLORIDE IN BULK AND PHARMACEUTICAL FORMULATION
}

\author{
PRASANTHI CHENGALVA ${ }^{1 *}$, MADHAVI KUCHANA ${ }^{2}$
}

${ }^{1}$ Krishna Teja Pharmacy College, Tirupati, Andhra Pradesh, India, ${ }^{2}$ Institute of Pharmaceutical Technology, Sri Padmavati Mahila Visvavidyalayam (Women's University), Tirupati, Andhra Pradesh, India Email: prashanthi.chengalva87@gmail.com

Received: 04 Jun 2019, Revised and Accepted: 06 Aug 2019

\section{ABSTRACT}

Objective: The objective of the present study is to develop simple, rapid, sensitive, accurate and economic stability-indicating ultra-performance liquid chromatographic (UPLC) method for the simultaneous quantification of phenylephrine hydrochloride, chlorpheniramine maleate, paracetamol, guaiphenesin and bromhexine hydrochloride in bulk and tablet dosage form.

Methods: The separation of drugs in the chromatographic column was accomplished on Hibar C18 (100 mm x $2.1 \mathrm{~mm}, 1.6 \mu \mathrm{m})$ column at a detection wavelength of $220 \mathrm{~nm}$. The mobile phase was a combination of sodium phosphate monobasic monohydrate buffer ( $\mathrm{p}^{\mathrm{H}}$ was adjusted to 3.5 with orthophosphoric acid) and acetonitrile in the ratio of $70: 30 \% \mathrm{v} / \mathrm{v}$ which was pumped at a flow rate of $0.3 \mathrm{ml} / \mathrm{min}$. The column temperature was maintained at $30^{\circ} \mathrm{C}$ and the injection volume was $0.3 \mu$ l. Forced degradation studies of drugs were carried out using acid, base, peroxide, light and heat.

Results: All the five drugs have been eluted within $3 \mathrm{~min}$. The retention times were found to be $0.834 \mathrm{~min}, 1.199 \mathrm{~min}, 1.600 \mathrm{~min}, 1.979 \mathrm{~min}$ and 2.525 min for phenylephrine, chlorpheniramine maleate, paracetamol, guaiphenesin and bromhexine respectively. The correlation coefficient $\left(\mathrm{r}^{2}\right)$ was found to be 0.999 for all the drugs. The recovery levels were found to be in the range of $98.06 \%$ to $100.28 \%$. RSD values of drugs were found to be below $2 \%$. The results of limit of detection and quantitation specified the sensitivity of the developed method. Significant degradation of drugs as a result of stress studies was found in acid, base and peroxide, but they were slightly degraded in photolytic and thermal conditions. The method has effectively resolved the degraded products. All the validation parameters were found to be within the limits according to International Conference on Harmonization (ICH) guidelines.

Conclusion: A simple and rapid UPLC method was established for the determination of five drugs. Hence, the proposed method can be employed for the quality control of specified drugs in bulk and pharmaceutical formulation even in the presence of degradation products.

Keywords: Phenylephrine hydrochloride, Chlorpheniramine maleate, Paracetamol, Guaiphenesin, Bromhexine hydrochloride, Stability indicating UPLC method

(C) 2019 The Authors. Published by Innovare Academic Sciences Pvt Ltd. This is an open-access article under the CC BY license (http://creativecommons.org/licenses/by/4.0/) DOI: http://dx.doi.org/10.22159/ijap.2019v11i5.34437

\section{INTRODUCTION}

Phenylephrine hydrochloride [fig. 1] is chemically 3-[(1R)-1hydroxy-2-(methylamino) ethyl] phenol hydrochloride is a sympathomimetic amine that acts predominantly on $\alpha$-adrenergic receptors and it is mainly used to treat nasal congestion.<smiles>CNCC(O)c1cccc(O)c1</smiles>

Fig. 1: Structure of phenylephrine hydrochloride

Chlorpheniramine maleate [fig. 2] is chemically but-2-enedioic acid; 3-(4-chlorophenyl)-N, N-dimethyl-3-pyridine-2-ylpropan-1-amine is a histamine H1-receptor antagonist used in allergic reactions, hay fever, rhinitis, urticaria and asthma.

Paracetamol [fig. 3] is chemically N-(4-hydroxyphenyl) acetamide is a p-aminophenol derivative is commonly used for its analgesic and antipyretic effects.<smiles>CN(C)CCC(c1ccc(Cl)cc1)c1ccccn1</smiles>

Fig. 2: Structure of chlorpheniramine maleate<smiles>CC(=O)Nc1ccc(O)cc1</smiles>

Fig. 3: Structure of paracetamol

Guaiphenesin [fig. 4] is chemically 3-(2-methoxyphenyl) propane1,2-diol is an expectorant and also has some muscle relaxing action. 
<smiles>COc1ccccc1OCC(O)CO</smiles>

Fig. 4: Structure of guaiphenesin

Bromhexine hydrochloride [fig. 5] is chemically 2,4-dibromo-6[[cyclohexyl(methyl) amino]methyl] aniline; hydrochloride act as an expectorant or mucolytic agent.<smiles>CN(Cc1cc(Br)cc(Br)c1N)C1CCCCC1</smiles>

Fig. 5: Structure of bromhexine hydrochloride

The combination of phenylephrine hydrochloride, chlorpheniramine maleate, paracetamol, guaiphenesin and bromhexine hydrochloride is available as tablets in the market till date which is used to treat cough, fever, cephalalgia, cold, catarrh, flu, hay fever and allergies due to food. Extensive literature survey revealed various analytical techniques for the estimation of mentioned drugs individually [1] and with other combinations [2-14]. An RP-HPLC method has been reported for the simultaneous estimation of phenylephrine hydrochloride, chlorpheniramine maleate, paracetamol, guaiphenesin and bromhexine hydrochloride in bulk and tablet dosage form [15]. In this method the retention time of analytes was high with a run time of $35 \mathrm{~min}$ thereby increasing the solvent consumption and leading to longer analysis time. The mode of separation was gradient and has used two mobile phases one of which was a combination of potassium dihydrogen phosphate buffer with octane-1-sulphonic acid reagent. Usage of buffers reduces the life of the column and preparation of mobile phases consumes more time, thereby increasing the analysis time. Hence, a rapid method is needed for the estimation of these drugs which can be attained by using UPLC technique with high sensitivity and less time of analysis. In addition to this, no UPLC method has been reported for the assay of specified drugs either individually or simultaneously in bulk and pharmaceutical formulation. Therefore, it was thought appropriate to develop stability-indicating ultra-performance liquid chromatographic procedure that serves as a rapid, simple, accurate, and sensitive method for the simultaneous estimation of phenylephrine hydrochloride, chlorpheniramine maleate, paracetamol, guaiphenesin and bromhexine hydrochloride in bulk and tablet dosage form. Further, it was aimed to validate the developed method as per validation of analytical procedures i.e. ICH guidelines: Q2[R1] Validation of Analytical Procedures: Text and Methodology.

\section{MATERIALS AND METHODS}

\section{Chemicals and reagents}

The commercially available formulation (Kuff Q NF tablets) containing phenylephrine hydrochloride $10 \mathrm{mg}$, chlorpheniramine maleate $2 \mathrm{mg}$, paracetamol $325 \mathrm{mg}$, guaiphenesin $100 \mathrm{mg}$ and bromhexine hydrochloride $8 \mathrm{mg}$, manufactured by Intas Pharmaceuticals Limited were purchased from local pharmacy.
Standard drugs were obtained from Spectrum Pharma Research Solutions, Hyderabad. Orthophosphoric acid, acetonitrile of analytical reagent grade and HPLC grade water was purchased from Rankem. Sodium phosphate monobasic monohydrate of AR grade was purchased from Sisco research laboratories.

\section{Instrument and equipment}

Acquity UPLC H-Class system (Waters) consists of a binary solvent manager, autosampler with UV detector. The output signal was monitored and processed using empower 2 software. Sonicator (LMUC-2, Labman scientific), $\mathrm{p}^{\mathrm{H}}$ meter (AD 1020, ADWA) and analytical balance (ER-200A, AFCOSET) were used.

\section{Chromatographic conditions}

The chromatographic column used was Hibar C18 (100 mm x 4.6 $\mathrm{mm} \times 1.8 \mu \mathrm{m})$. The separation was achieved on isocratic mode. The mobile phase consists of sodium phosphate monobasic monohydrate buffer whose $\mathrm{p}^{\mathrm{H}}$ was adjusted to 3.5 with orthophosphoric acid and acetonitrile in the ratio of $70: 30 \% \mathrm{v} / \mathrm{v}$ was pumped at a flow of $0.3 \mathrm{ml} / \mathrm{min}$. The column temperature was maintained at $30{ }^{\circ} \mathrm{C}$ with an injection volume of $0.3 \mu \mathrm{l}$ and the detector was monitored at $220 \mathrm{~nm}$ with a total run time of $5 \mathrm{~min}$.

\section{Preparation of buffer solution}

The buffer solution of $50 \mathrm{mmol}$ sodium phosphate monobasic monohydrate was prepared by weighing $6.89 \mathrm{~g}$ of sodium phosphate monobasic monohydrate and transferred into $1000 \mathrm{ml}$ volumetric flask. About $950 \mathrm{ml}$ of milli-Q water was added, degassed and sonicated for 20 min and finally, the volume was made up with water then the $\mathrm{p}^{\mathrm{H}}$ was adjusted to 3.5 with orthophosphoric acid.

\section{Preparation of diluent}

The diluent was prepared by taking water and acetonitrile in the ratio 50:50.

\section{Preparation of standard solution}

The standard stock solution was prepared by weighing $2.5 \mathrm{mg}$ of phenylephrine hydrochloride, $0.5 \mathrm{mg}$ of chlorpheniramine maleate, $81.25 \mathrm{mg}$ paracetamol, $25 \mathrm{mg}$ of guaiphenesin and $2 \mathrm{mg}$ of bromhexine hydrochloride and transferred to $25 \mathrm{ml}$ volumetric flask. To this $10 \mathrm{ml}$ of diluent was added, sonicated for $25 \mathrm{~min}$ and the volume was made up with diluent. From the above standard stock solution $1 \mathrm{ml}$ was transferred into $10 \mathrm{ml}$ volumetric flask and made up to the volume with diluent so as to get final concentration of $10 \mu \mathrm{g} / \mathrm{ml}$ of phenylephrine hydrochloride, $2 \mu \mathrm{g} / \mathrm{ml}$ of chlorpheniramine maleate, $325 \mu \mathrm{g} / \mathrm{ml}$ of paracetamol, $100 \mu \mathrm{g} / \mathrm{ml}$ of guaiphenesin and $8 \mu \mathrm{g} / \mathrm{ml}$ of bromhexine hydrochloride.

\section{Preparation of sample solution}

From the blend of 20 tablets, the weight of powder equivalent to one tablet was transferred into a $100 \mathrm{ml}$ volumetric flask, to this $50 \mathrm{ml}$ of diluent was added and sonicated for $25 \mathrm{~min}$; further the volume was made up with diluent and filtered. From the filtered solution $1 \mathrm{ml}$ was transferred into $10 \mathrm{ml}$ volumetric flask and made up to the volume with diluent.

\section{Preparation of samples for forced degradation}

During stress studies, degradation in acidic medium was carried out by taking $1 \mathrm{ml}$ of standard stock solution, to this $1 \mathrm{ml}$ of $1 \mathrm{~N} \mathrm{HCl}$ was added and refluxed for $30 \mathrm{~min}$ at $60{ }^{\circ} \mathrm{C}$. The resultant solution was neutralized by adding $1 \mathrm{ml}$ of $1 \mathrm{~N} \mathrm{NaOH}$ solution and diluted to 10 $\mathrm{ml}$ with diluent. Forced degradation in the basic medium was performed by taking $1 \mathrm{ml}$ of standard stock solution, to this $1 \mathrm{ml}$ of 1 $\mathrm{N} \mathrm{NaOH}$ was added and refluxed for $30 \mathrm{~min}$ at $60^{\circ} \mathrm{C}$. The resultant solution was neutralized using $1 \mathrm{~N} \mathrm{HCl}$ solution and diluted to $10 \mathrm{ml}$ with diluent. For oxidative degradation, $1 \mathrm{ml}$ of $10 \%$ hydrogen peroxide was added to $1 \mathrm{ml}$ of standard stock solution. The solution was kept for $30 \mathrm{~min}$ at $60^{\circ} \mathrm{C}$. The resultant solution was diluted to $10 \mathrm{ml}$ with diluent. For thermal degradation, the standard stock solution was taken in a beaker and placed in oven at $60^{\circ} \mathrm{C}$ for $6 \mathrm{~h}$ and $1 \mathrm{ml}$ from the resultant solution was diluted to $10 \mathrm{ml}$ with diluent. For photostability studies, a volume of $5 \mathrm{ml}$ from stock 
solution was taken in a beaker and kept under UV light in UV chamber for $3 \mathrm{~d}$. From the resultant solution $1 \mathrm{ml}$ was taken and diluted up to $10 \mathrm{ml}$ with diluent.

\section{Method validation}

The developed method was validated for specificity, accuracy, precision, linearity, limit of detection (LOD), the limit of quantitation (LOQ) and robustness according to ICH guidelines [16].

\section{Specificity}

Specificity of the method was performed to analyse the interference of solvent and impurities with the analyte peaks. To determine this, blank and generated impurities by forced degradation were injected into the chromatographic system and observed for any interfering peaks at the retention time of analytes peak.

\section{Accuracy}

Accuracy was performed to ensure the reliability and accuracy of the method by recovery studies which was carried out by standard addition method. The known quantities of pure drugs were added to the pre-analyzed sample at three concentration levels $50 \%, 100 \%$, $150 \%$ in three replicates and contents were reanalyzed by the proposed method and the percent recovery were calculated.

\section{Precision}

Precision was performed to check the repeatability of the developed method. The standard solution was prepared at working concentration and injected six times into the chromatographic system. The percentage relative standard deviation was calculated.

\section{Linearity}

The linearity of the method was determined by preparing the solutions at five different concentration levels with standard drugs, which was from $25 \%$ to $150 \%$ of target assay concentration. The calibration curves were plotted between peak area and concentration. The least square linear regression were carried and correlation coefficient $\left(\mathrm{r}^{2}\right)$ values were observed to check the linearity.

\section{Limit of detection (LOD) and limit of quantitation (LOQ)}

LOD is the minimum concentration at which analyte can be detected and calculated from the linearity curve by applying the formula:

$$
\mathrm{LOD}=3.3 \times \mathrm{SD} / \mathrm{S}
$$

LOQ is the lowest concentration of the analyte that can be estimated quantitatively by applying the formula:

$$
\mathrm{LOQ}=10 \times \mathrm{SD} / \mathrm{S}
$$

Where $\mathrm{SD}=$ Standard deviation of $\mathrm{y}$-intercepts; $\mathrm{S}=$ Slope of the calibration curve.

\section{Robustness}

Robustness of the developed method was established by deliberately changing the method parameters such as flow rate $( \pm 0.1$ $\mathrm{ml} / \mathrm{min})$, column temperature $\left( \pm 5^{\circ} \mathrm{C}\right)$ and mobile phase ratio $( \pm 5 \%)$ to evaluate the impact of these conditions on the method and the system suitability parameters were evaluated for the studies.

\section{Forced degradation studies}

Forced degradation or stress testing was undertaken to demonstrate specificity during the development of stability-indicating assay method. It is the specific one, which evaluates the drug in the presence of its degradation products. The percentage of drug degraded under stressed conditions was calculated and also observed for the interference of degraded products peak at the retention times of analyte peaks.

\section{RESULTS AND DISCUSSION}

\section{Method development}

After many trials made by altering the chromatographic conditions like mobile phase, $\mathrm{p}^{\mathrm{H}}$ of the selected mobile phases, detection wavelengths and injection volume to resolve all the five drugs, the obtained peaks were sharp with good resolution using a mobile phase of sodium phosphate monobasic monohydrate buffer, $\mathrm{p}^{\mathrm{H}}$ adjusted to 3.5 with orthophosphoric acid and acetonitrile in the ratio $70: 30 \% \mathrm{v} / \mathrm{v}$ which was pumped at a flow rate of $0.3 \mathrm{ml} / \mathrm{min}$ and at a detection wavelength $220 \mathrm{~nm}$. The corresponding optimized chromatogram obtained for a standard solution of analytes was shown [fig. 6]. The system suitability parameters such as theoretical plates, resolution, tailing factor were determined and presented in the table 1 and the parameters were found to be within limits. All the drugs were eluted within 3 min with isocratic mode which specify an absolute rapidity of the method when compared to the reported RP-HPLC method where the elution of drugs took up to 25 min on gradient mode [15].

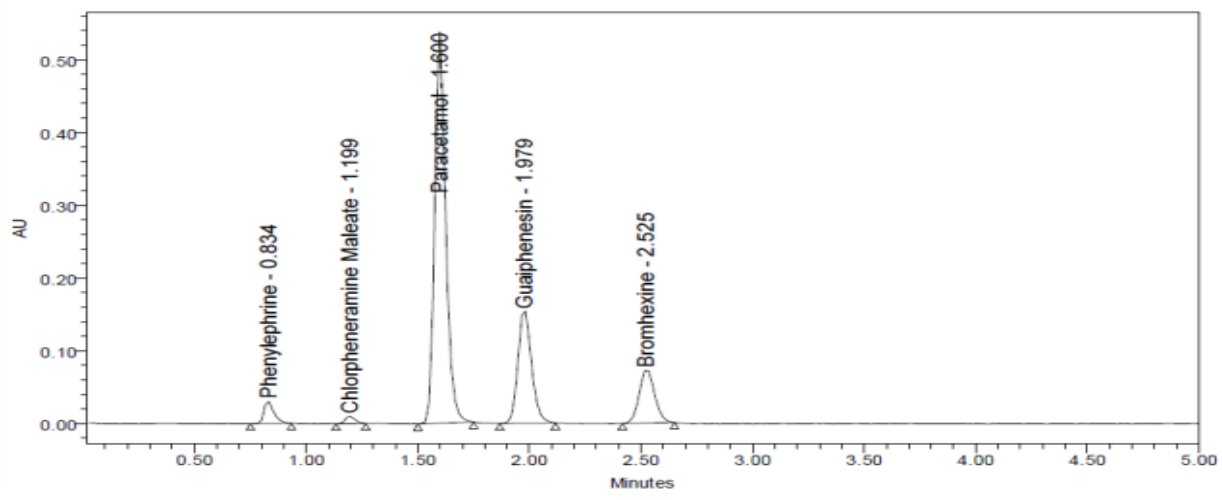

Fig. 6: Typical chromatogram of standards

\begin{tabular}{|c|c|c|c|c|c|}
\hline Drug name & Retention time* (min) & Resolution* & Plate count ${ }^{*}$ & Tailing factor* & Peak area* \\
\hline Phenylephrine & $0.834 \pm 0.03$ & - & $6576.1 \pm 173.7$ & $1.3 \pm 0.01$ & $96250 \pm 544.5$ \\
\hline Chlorpheniramine maleate & $1.199 \pm 0.10$ & $4.2 \pm 0.2$ & $3164.8 \pm 451.6$ & $1.1 \pm 0.14$ & $31280 \pm 220.7$ \\
\hline Paracetamol & $1.600 \pm 0.10$ & $4.4 \pm 0.1$ & $4795.6 \pm 81.1$ & $1.2 \pm 0.03$ & $1938223 \pm 15007.9$ \\
\hline Guaiphenesin & $1.979 \pm 0.01$ & $3.6 \pm 0.1$ & $5048.3 \pm 175.2$ & $1.1 \pm 0.01$ & $683832 \pm 1809.6$ \\
\hline Bromhexine & $2.525 \pm 0.02$ & $4.5 \pm 0.1$ & $6379.3 \pm 96.7$ & $1.1 \pm 0.01$ & $387727 \pm 2718.4$ \\
\hline
\end{tabular}

Table 1: Results of system suitability studies

*Each value is represented as a mean \pm SD of 6 observations 


\section{Method validation}

\section{Specificity}

After the injection of blank and degradation samples into the chromatographic system, no interfering peaks have been observed at the retention times of analyte peaks. Hence, the method was found to be specific for the estimation of drugs.

\section{Accuracy}

The results of accuracy were presented in table 2. Recovery studies were carried out at three concentration levels for three times each.
From the accuracy data, it was found that the recoveries were within the specified range. The results of accuracy decisively specify that the recovery values were within the acceptance range of 98-102 \%. Hence, the developed method was accurate for the determination of the above mentioned drugs.

\section{Precision}

From the results of precision studies which were tabulated in table 3 , the RSD values for peak areas were found to be less than $2 \%$. This surely assures that the developed method was precise and repeatable.

Table 2: Results of accuracy studies

\begin{tabular}{|c|c|c|c|c|}
\hline Name of the analyte & Accuracy level (\%) & ${ }^{*}$ Concentration spiked $(\mu \mathrm{g} / \mathrm{ml})$ & * Concentration found $(\mu \mathrm{g} / \mathrm{ml})$ & $\begin{array}{l}* \text { Mean } \\
\% \text { recovery }\end{array}$ \\
\hline \multirow[t]{3}{*}{ Phenylephrine } & 50 & 5 & 4.94 & 98.92 \\
\hline & 100 & 10 & 9.95 & 99.55 \\
\hline & 150 & 15 & 14.97 & 100.28 \\
\hline \multirow[t]{3}{*}{ Chlorpheniramine maleate } & 50 & 1 & 0.99 & 99.16 \\
\hline & 100 & 2 & 2.01 & 100.03 \\
\hline & 150 & 3 & 2.96 & 98.72 \\
\hline \multirow[t]{3}{*}{ Paracetamol } & 50 & 162.5 & 161.35 & 99.29 \\
\hline & 100 & 325 & 322.49 & 99.22 \\
\hline & 150 & 487.5 & 487.18 & 99.93 \\
\hline \multirow[t]{3}{*}{ Guaiphenesin } & 50 & 50 & 49.62 & 99.25 \\
\hline & 100 & 100 & 99.76 & 99.76 \\
\hline & 150 & 150 & 150.17 & 100.11 \\
\hline \multirow[t]{3}{*}{ Bromhexine } & 50 & 4 & 3.97 & 99.44 \\
\hline & 100 & 8 & 7.94 & 99.34 \\
\hline & 150 & 12 & 12.01 & 100.07 \\
\hline
\end{tabular}

*Average of triplicate determinations, Acceptence criteria: \% recovery must be $98 \%-102 \%$

Table 3: Results of precision studies

\begin{tabular}{ll}
\hline Name of the analyte & RSD*(\%) \\
\hline Phenylephrine & 0.2 \\
Chlorpheniramine maleate & 0.4 \\
Paracetamol & 0.6 \\
Guaiphenesin & 0.4 \\
Bromhexine & 0.5 \\
\hline
\end{tabular}

${ }^{*}$ RSD values for six determinations, RSD: Relative Standard Deviation, Acceptance criteria: RSD $=<2 \%$

\section{Linearity and range}

The results of linearity were given in table 4 and the representative calibration plots were shown [fig. 7-11]. The data was treated by leastsquare linear regression analysis and the correlation coefficients for all the drugs was found to be 0.999 over the specified range of 25-150\% of target assay concentrations. The results indicate linear and directly proportional relationship between the concentration of specified range and response which meet the method validation acceptance criteria ( $r^{2}$ must be $\left.0.990-1\right)$ and hence the method was said to be linear for the specified concentration range.

\section{LOD and LOQ}

By applying the formula method, the LOD values were found to be $0.06 \mu \mathrm{g} / \mathrm{ml}$ for phenylephrine, $0.03 \mu \mathrm{g} / \mathrm{ml}$ for chlorpheniramine maleate, $1.06 \mu \mathrm{g} / \mathrm{ml}$ for paracetamol, $0.89 \mu \mathrm{g} / \mathrm{ml}$ for guaiphenesin and $0.09 \mu \mathrm{g} / \mathrm{ml}$ for bromhexine. The LOQ values were found to be $0.17 \mu \mathrm{g} / \mathrm{ml}$ for phenylephrine, $0.08 \mu \mathrm{g} / \mathrm{ml}$ for chlorpheniramine maleate, $3.22 \mu \mathrm{g} / \mathrm{ml}$ for paracetamol, $2.71 \mu \mathrm{g} / \mathrm{ml}$ for guaiphenesin and $0.28 \mu \mathrm{g} / \mathrm{ml}$ for bromhexine. The results of LOD and LOQ perfectly indicate the sensitivity of the developed UPLC method.

\section{Robustness}

The degraded sample solutions were prepared as per the test method and injected at different variable conditions, system suitability parameters were assessed. The results of robustness was presented in table 5 and 6 , it was found that the parameters such as tailing factor, plate count were within the limits even after small but deliberate alterations. From the results, it was concluded that even small changes that have made in the chromatographic conditions did not affect significantly on system suitability parameters and found to be within limits. Hence, the developed method was robust.

Table 4: Results of linearity

\begin{tabular}{lll}
\hline Name of the analyte & Linearity range $(\boldsymbol{\mu g} / \mathbf{m l})$ & Correlation coefficient $\left(\mathbf{r}^{2}\right)$ \\
\hline Phenylephrine & $2.5-15$ & 0.999 \\
Chlorpheniramine maleate & $0.5-3$ & 0.999 \\
Paracetamol & $81.25-487.5$ & 0.999 \\
Guaiphenesin & $25-150$ & 0.999 \\
Bromhexine & $2-12$ & 0.999 \\
\hline
\end{tabular}

Acceptance criteria: Correlation coefficient $\left(r^{2}\right)$ must be from 0.999-1 


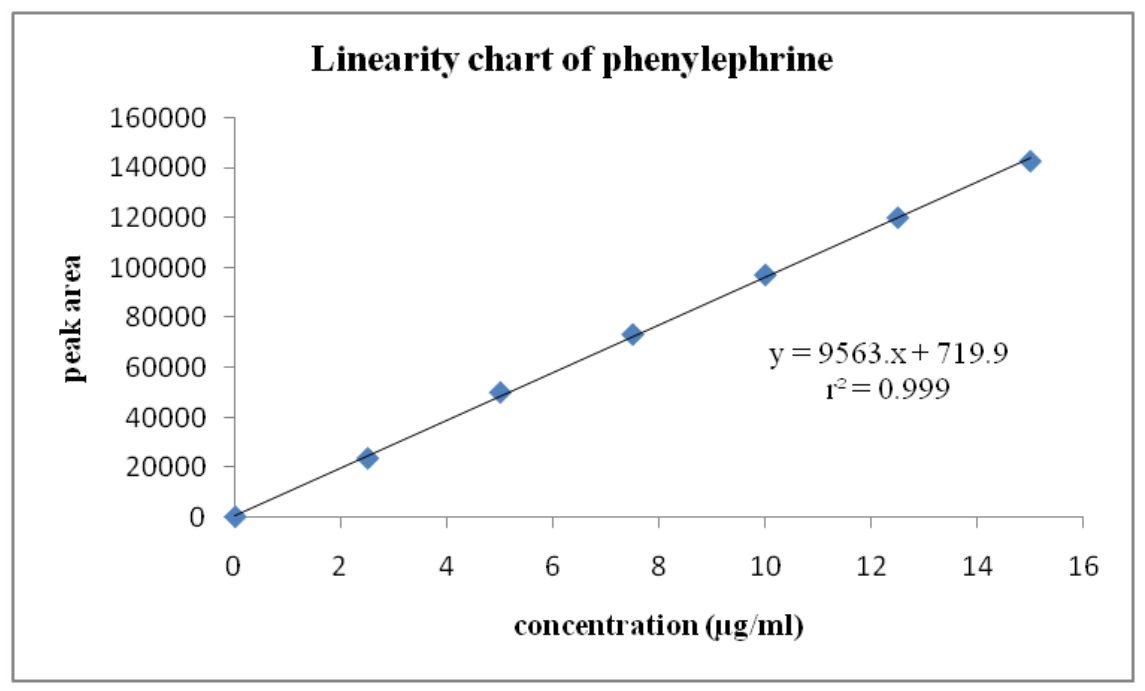

Fig. 7: Calibration plot of phenylephrine

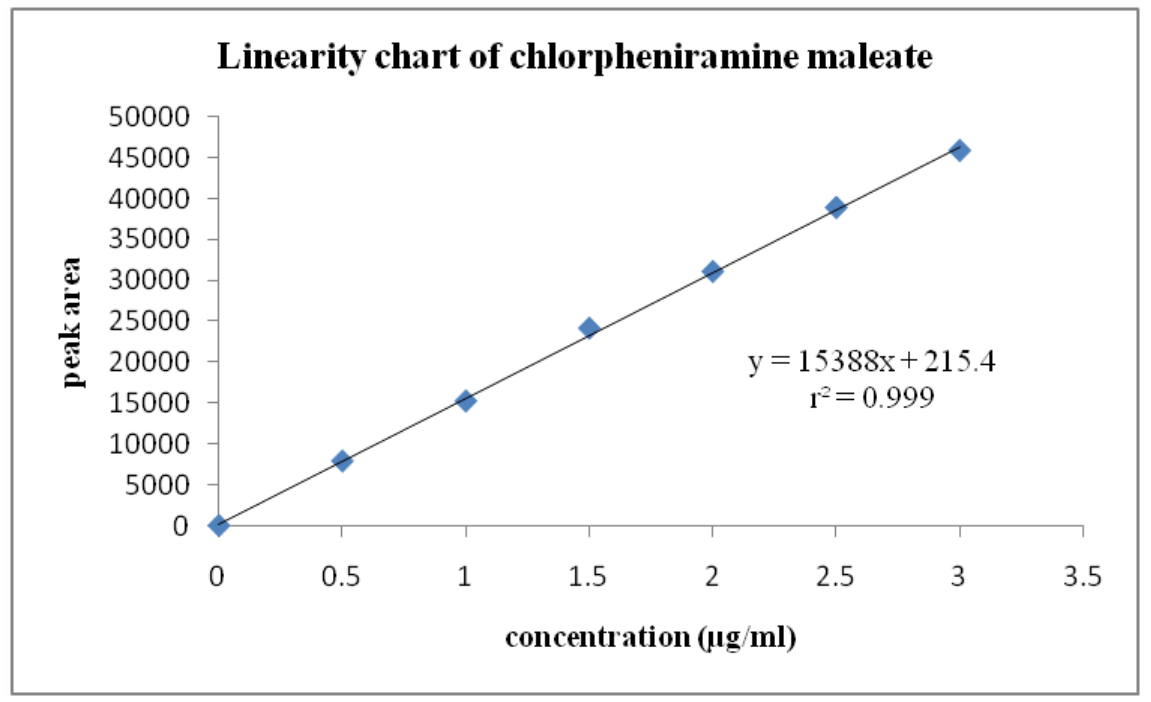

Fig. 8: Calibration plot of chlorpheniramine maleate

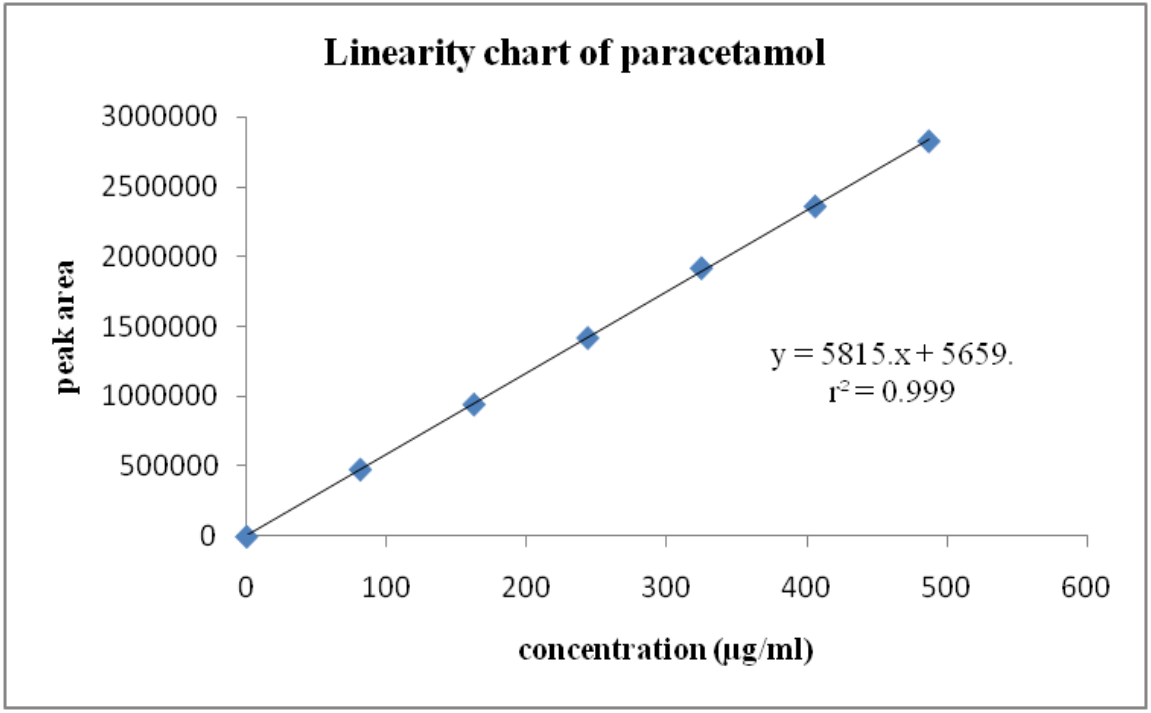

Fig. 9: Calibration plot of paracetamol 


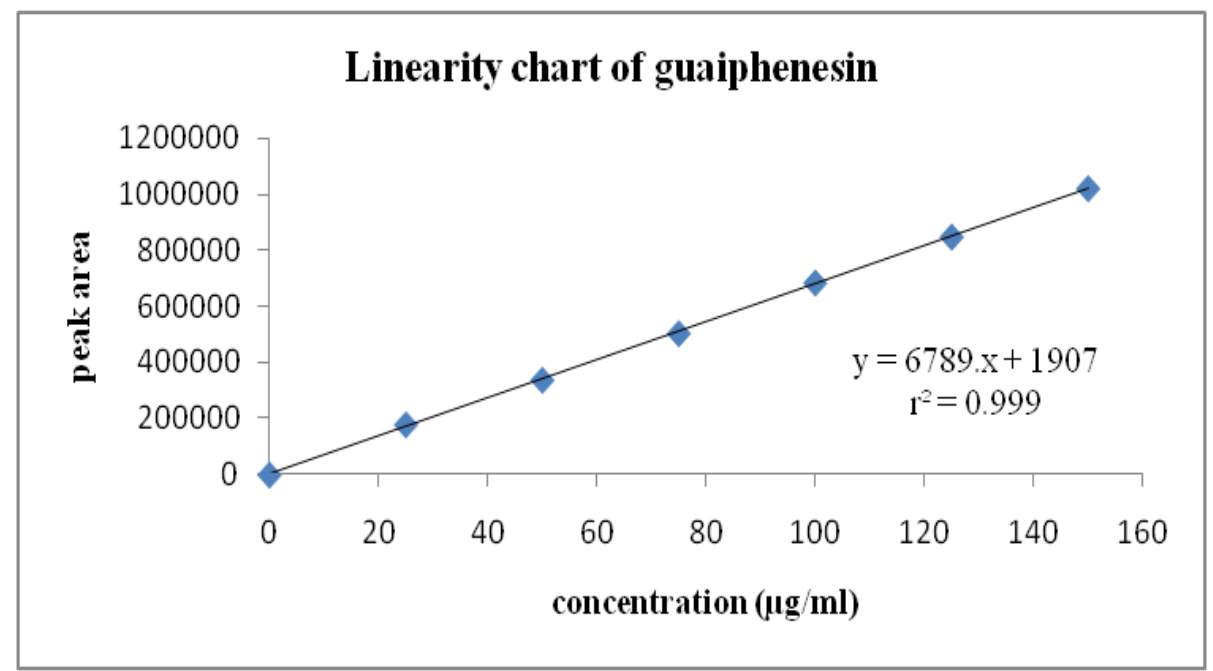

Fig. 10: Calibration plot of guaiphenesin

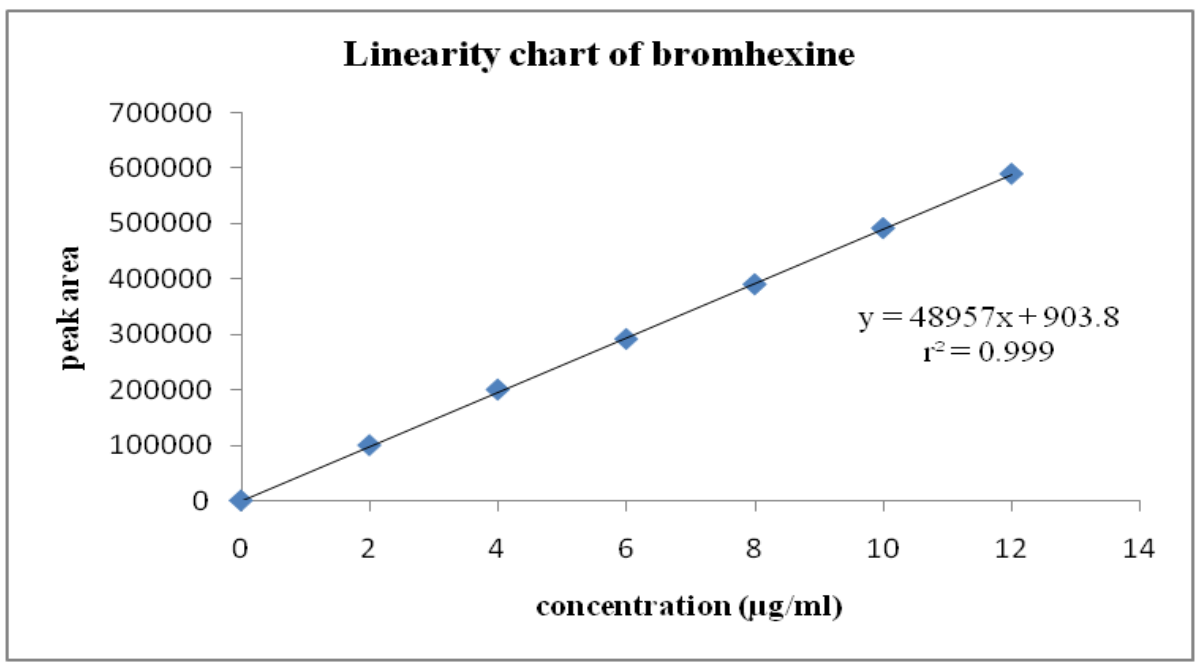

Fig. 11: Calibration plot of bromhexine

Table 5: Results of robustness for phenylephrine and chlorpheniramine maleate

\begin{tabular}{llll}
\hline Parameter & \multicolumn{2}{l}{ Phenylephrine } & \multicolumn{2}{l}{ Thlorpheniramine maleate $^{*}$} \\
\cline { 2 - 4 } & Tailing* & Plate count $^{\#}$ & 1.08 \\
\hline Less flow rate $(0.2 \mathrm{ml} / \mathrm{min})$ & 1.42 & 6589 & 3195 \\
More flow rate $(0.4 \mathrm{ml} / \mathrm{min})$ & 1.38 & 6482 & 1.11 \\
Less column temperature $\left(25^{\circ} \mathrm{C}\right)$ & 1.41 & 6465 & 1.22 \\
More column temperature $\left(35^{\circ} \mathrm{C}\right)$ & 1.40 & 6781 & 1.05 \\
Less organic phase $(75: 25)$ & 1.32 & 6467 & 1.53 \\
More organic phase $(65: 35)$ & 1.17 & 6752 & 2451 \\
\hline
\end{tabular}

Acceptance criteria: *Tailing: <2, \#Plate count: $>2000$

Table 6: Results of robustness for paracetamol, guaphenesin and bromhexine

\begin{tabular}{|c|c|c|c|c|c|c|}
\hline \multirow[t]{2}{*}{ Parameter } & \multicolumn{2}{|c|}{ Paracetamol } & \multicolumn{2}{|c|}{ Guaiphenesin } & \multicolumn{2}{|c|}{ Bromhexine } \\
\hline & Tailing* & Plate count ${ }^{\#}$ & Tailing* & Plate count ${ }^{\#}$ & Tailing* & Plate count $^{\#}$ \\
\hline Less flow rate $(0.2 \mathrm{ml} / \mathrm{min}$ & 1.21 & 5195 & 1.16 & 5535 & 1.12 & 6676 \\
\hline More flow rate $(0.4 \mathrm{ml} / \mathrm{min})$ & 1.19 & 4695 & 1.14 & 5360 & 1.14 & 6182 \\
\hline Less column temperature $\left(25^{\circ} \mathrm{C}\right)$ & 1.21 & 4880 & 1.14 & 5285 & 1.10 & 6340 \\
\hline More column temperature $\left(35^{\circ} \mathrm{C}\right)$ & 1.19 & 4632 & 1.09 & 5213 & 1.07 & 6765 \\
\hline Less organic phase $(75: 25)$ & 1.12 & 5032 & 1.10 & 5446 & 1.07 & 7070 \\
\hline More organic phase $(65: 35)$ & 1.22 & 5129 & 1.07 & 5346 & 1.12 & 6554 \\
\hline
\end{tabular}

Acceptance criteria: *Tailing: <2, \#Plate count: $>2000$ 


\section{Forced degradation studies}

Standard and degraded samples were injected into the system with a run time of $10 \mathrm{~min}$ and the results were given in table 7 . The degradation assay chromatograms were shown [fig. 12-16]. The percentage of drug degraded in solution was calculated. The degradation products produced as a result of stress studies did not interfere with the detection of analytes. Significant degradation was found in the presence of acid, base and peroxide. It was found that the drugs were slightly degraded in photolytic and thermal conditions. Therefore, the assay was considered as stabilityindicating.

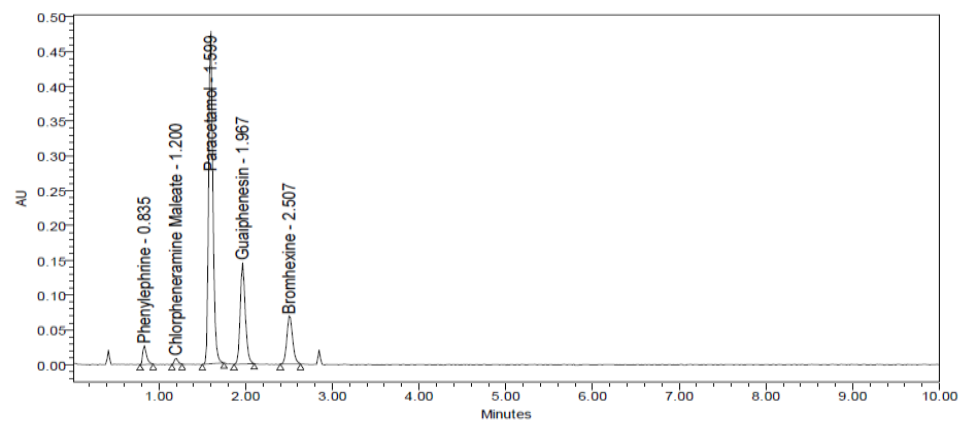

Fig. 12: Chromatogram of acid degradation

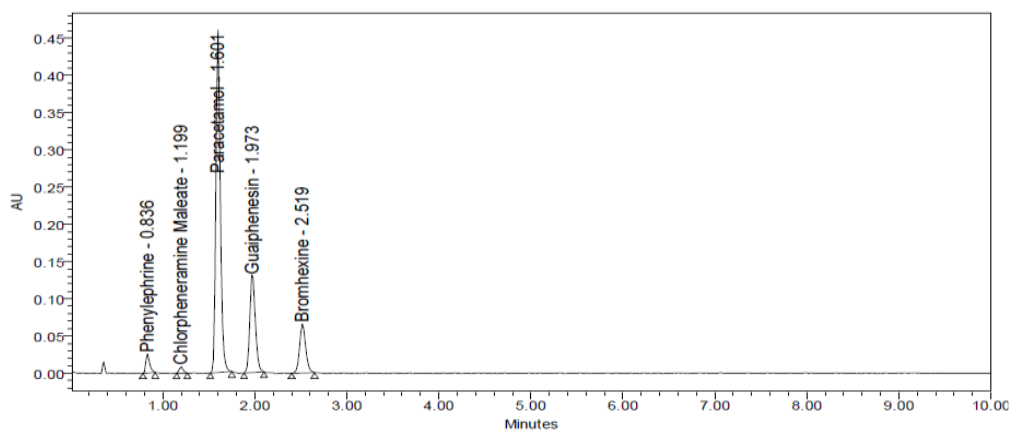

Fig. 13: Chromatogram of base degradation

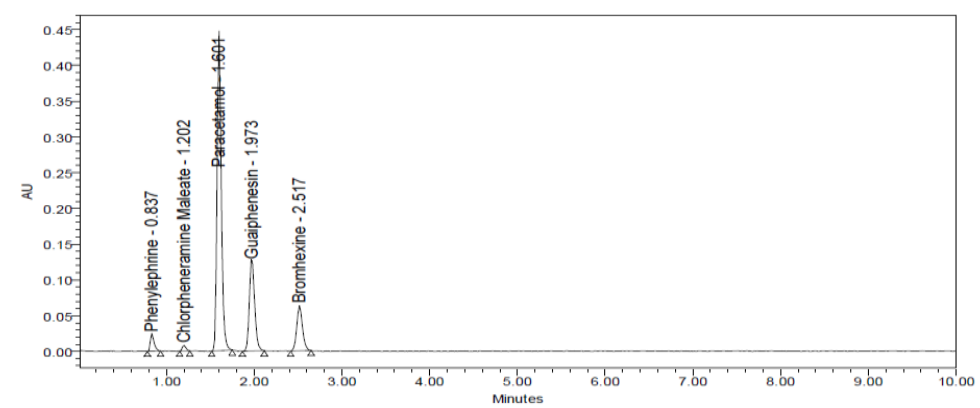

Fig. 14: Chromatogram of peroxide degradation

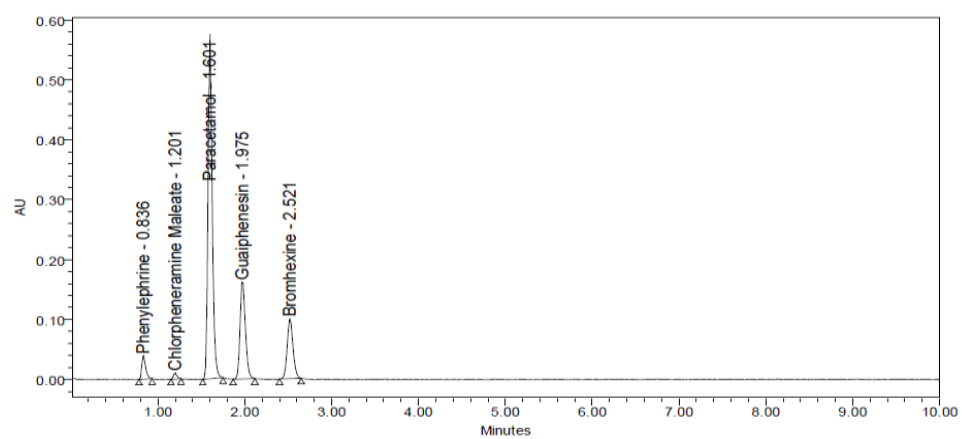

Fig. 15: Chromatogram of thermal degradation 


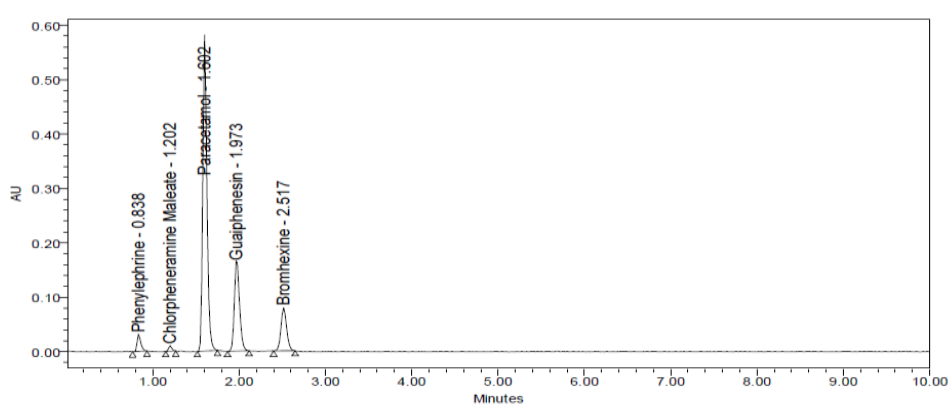

Fig. 16: Chromatogram of photodegradation

Table 7: Results of forced degradation studies

\begin{tabular}{|c|c|c|c|c|c|}
\hline \multirow[t]{2}{*}{ Stress conditions } & Phenylephrine & Chlorpheniramine maleate & Paracetamol & Guaiphenesin & Bromhexine \\
\hline & \multicolumn{5}{|l|}{ \% Degraded } \\
\hline Acid & 4.60 & 5.50 & 4.56 & 5.09 & 5.85 \\
\hline Base & 3.91 & 4.72 & 3.73 & 4.27 & 4.99 \\
\hline Peroxide & 3.64 & 3.82 & 3.06 & 3.78 & 3.44 \\
\hline Thermal & 2.82 & 2.36 & 2.23 & 2.36 & 2.66 \\
\hline Photolysis & 1.81 & 1.91 & 1.80 & 1.91 & 1.33 \\
\hline
\end{tabular}

\section{Assay of marketed formulation}

The applicability of the developed method was verified by assaying the marketed formulation. Kuff $Q \mathrm{NF}$ tablets were analyzed by standard comparison method. The prepared standard and sample solutions were injected into the chromatographic system and the amount of drug present in the formulation was calculated and the results were tabulated in table 8 . The results complied with the label claim and specify that the developed method was successfully applied for quality control of formulation.

Table 8: Results of assay of formulation

\begin{tabular}{|c|c|c|c|c|c|}
\hline S. No. & Phenylephrine & Chlorpheniramine maleate & Paracetamol & Guaiphenesin & Bromhexine \\
\hline \multicolumn{6}{|c|}{$\%$ Assay } \\
\hline 1 & 99.86 & 99.83 & 99.63 & 99.93 & 99.22 \\
\hline 2 & 99.90 & 99.66 & 99.32 & 99.25 & 100.59 \\
\hline 3 & 99.95 & 99.45 & 99.05 & 99.87 & 99.61 \\
\hline 4 & 99.85 & 99.67 & 99.86 & 99.10 & 99.49 \\
\hline 5 & 99.86 & 100.53 & 100.87 & 99.06 & 99.91 \\
\hline 6 & 100.48 & 99.84 & 99.58 & 99.38 & 100.35 \\
\hline Mean & 99.98 & 99.83 & 99.72 & 99.43 & 99.86 \\
\hline
\end{tabular}

Acceptance criteria: \% Assay must be in the range of 98-102 \%

\section{CONCLUSION}

The developed isocratic, reverse phase UPLC method was found to be rapid, simple, accurate, precise and stability-indicating for the simultaneous estimation of phenylephrine hydrochloride, chlorpheniramine maleate, paracetamol, guaiphenesin and bromhexine hydrochloride in bulk and pharmaceutical formulation. The method can be used to estimate the drugs either individually or simultaneously in bulk and pharmaceutical formulation. This method has effectively resolved all the drugs and their degradation products. Thus, it was found to be more specific and selective for the estimation of above-specified drugs. The flow of mobile phase was set at very low rate, and has very less elution time and hence the method has advantages of less solvent consumption and faster analysis. Therefore, the developed method can be considered as economic for the estimation of five drugs simultaneously. Finally, it was concluded that the developed analytical method can be employed for the routine quality control of drugs in bulk and pharmaceutical formulation even in the presence of degraded impurities.

\section{ACKNOWLEDGMENT}

Authors sincerely express gratitude to the principal of Krishna Teja Pharmacy College, Tirupati and Spectrum Pharma Research Solutions, Hyderabad for providing necessary facilities to carry out this research work.

\section{AUTHORS CONTRIBUTIONS}

All the authors have contributed equally

\section{CONFLICT OF INTERESTS}

Declared none

\section{REFERENCES}

1. Ramya V, Vijaya Lakshmi M, Pravallika M, Buchi NN. Novel RPHPLC-PDA method for the estimation of chlorpheniramine maleate in bulk and dosage forms. Indo Am J Pharm Res 2016;6:6439-44.

2. Blessy S, Prasanthi C, Parameswari S, Aruna G. A novel HPLC method for the simultaneous determination of chlorpheniramine maleate and dextromethorphan in bulk and pharmaceutical formulation. Int J Pharm Sci Res 2018;9:1147-51.

3. Magesh AR, Dhanaraju MD. Development and validation of RPHPLC method for simultaneous estimation of diethylcarbamazine citrate and chlorpheniramine maleate in pharmaceutical preparations. Chem Sci Trans 2017;6:316-22.

4. Satyanarayanamurthy R, Hanimireddy B, Maramravikumar B, Joy sunandan B. RP-HPLC method development and validation for quantification of paracetamol and ibuprofen and its related impurities in the solid dosage form. Int J Pharma Bio Sci 2017;8:152-68. 
5. Neelima G, Sreerama R, Prasanth Kumar T, Immanuel A, Prayas A. Development and validation of RP-HPLC method for simultaneous estimation of guaifenesin and pseudoephedrine $\mathrm{HCl}$ in extended-release tablet dosage form. Der Pharm Chem 2017;9:43-7.

6. Kapildev RJ. Analytical method development and validation of RP-HPLC for simultaneous estimation of chlorpheniramine maleate, dextromethorphan hydrobromide, phenylephrine hydrochloride in cough syrup. Int J Adv Sci Eng Inf Technol 2016;4:35-9.

7. Jivani N, Hitesh V, Hetal P. Stability indicating HPLC method development and validation for simultaneous estimation of bromhexine and phenylephrine $\mathrm{HCl}$ in its combined pharmaceutical dosage form. J Pharm Sci Biosci Res 2016;6:523-8

8. Vanita D, Jinal T, Paya C, Samir S. A novel stability-indicating RPHPLC method development and validation for estimation of phenylephrine hydrochloride and bromhexine hydrochloride in their tablet dosage form. Int J Curr Pharm Res 2016;6:1839-51.

9. Vijay Kumar R, Vinay UR. A novel stability-indicating RP-HPLC method development and validation for simultaneous estimation of phenylephrine, acetaminophen, guaifenesin and dextromethorphan in the tablet dosage form. Pharm Lett 2015;7:329-39.

10. Ali A, Ahmed M, Mahmud T, Qadir MA, Nadeem K, Saleem A. Stability is indicating high-performance liquid chromatography method for simultaneous determination of aminophylline and chlorpheniramine maleate in pharmaceutical formulations. Indian J Pharm Sci 2015;77:515-21.

11. Allabasha M, Iffath R. Simultaneous estimation of paracetamol, ibuprofen and famotidine by using RP-HPLC method. Indo Am J Pharm Res 2015;5:2965-80.

12. Ankit B, Shweta MB, Chintal MS. Development and validation of RP-HPLC method for simultaneous estimation of bromhexine hydrochloride, guaiphenesin and chlorpheniramine maleate in tablet. World J Pharm Pharm Sci 2015;4:1679-94.

13. Rani S, Ritu M, Satish Y. Liquid chromatography-tandem mass spectrometry method development and validation for the simultaneous analysis of paracetamol, guaifenesin, phenylephrine hydrochloride, chlorpheniramine maleate, and ambroxol hydrochloride in bulk and in tablet dosage form. Asian J Pharm Clin Res 2018;11:375-82.

14. Fitria A, Muchlisyam B, Siti Morin S. Development and validation of double divisor ratio spectra derivative spectrophotometry method for a ternary mixture of guaifenesin, dextromethorphan $\mathrm{HBr}$, and diphenhydramine $\mathrm{HCl}$ in tablet dosage form. Asian J Pharm Clin Res 2018;11:1-3.

15. Nalini K, Narmada P, Vijay Lakshmi G, Yogi K. Simultaneous estimation of paracetamol, guaiphensin, phenylephrine $\mathrm{HCl}$, chlorpheniramine maleate, bromhexine $\mathrm{HCl}$ in combined tablet dosage form by RP-HPLC. Int J Pharm Sci Res 2014;5:410-6.

16. International conference on harmonization tripartite guideline on validation of analytical procedures text and methodology: Q2 (R1); 2005. 